\title{
OCENA LOGISTYKI MIEJSKIEJ W ZAKRESIE TRANSPORTU ZBIOROWEGO NA PRZYKLADZIE TOMASZOWA MAZOWIECKIEGO I RZESZOWA
}

\begin{abstract}
Współczesna logistyka zajmuje się miastem w dwóch aspektach. Po pierwsze, traktuje je jako ogniwo łańcucha logistycznego w systemie logistycznym kraju, po drugie, jako samoistny system miejski. Na system logistyczny miasta składają się poszczególne systemy funkcjonalne. Zaliczają się do nich: transport, obejmujący transport dóbr materialnych, w tym również przesył mediów, transport i składowanie odpadów komunalnych, komunikacja zbiorowa i indywidualna, składowanie dóbr materialnych $\mathrm{w}$ dzielnicach przemysłowohandlowych i w sieciach handlowych miasta i sterowanie przepływami dóbr materialnych i osób. Warto zaznaczyć, że 1/3 wszystkich ruchów transportowych w mieście to transport gospodarczy towarowy, a $2 / 3$ to transport osobowy zarówno indywidualny, jak i publiczny. Przemieszczenia osobowe mogą się odbywać przy użyciu transportu indywidualnego albo przy użyciu komunikacji zbiorowej. Współcześnie indywidualny transport zmotoryzowany zaczyna stanowić poważne zagrożenie dla sprawnego funkcjonowanie miasta i płynnego transportu. Dlatego coraz bardziej istotne stają się działania mające doprowadzić do zmian przyzwyczajeń, preferencji i mentalności mieszkańców. Bardzo ważne są pod tym względem rola władz miasta i działania, które podejmują w celu zmniejszenia transportu indywidualnego. Powinno to spowodować większe zainteresowanie transportem zbiorowym. Celem badań prowadzonych przez autorów jest poznanie oceny funkcjonowania komunikacji miejskiej w dwóch różnej wielkości ośrodkach miejskich: średniego miasta Tomaszowa Mazowieckiego i dużego miasta, jakim jest Rzeszów. Badania miały charakter ankietowy i przeprowadzono je z mieszkańcami obu badanych miast.

Słowa kluczowe: logistyka, komunikacja, miasto, mieszkańcy
\end{abstract}

\section{WSTEP}

Zainteresowanie logistyką miejską wynika z przestrzennego rozrastania się miast, wzrostu gęstości zaludnienia, zwiększającej się liczby instytucji i firm. Miasto w ujęciu koncepcji logistycznych to socjalnie zurbanizowany teren, który można postrzegać w dwóch aspektach: jako ogniwo łańcucha logistycznego w systemie logistycznym kraju i jako samoistny system miejski. Na system logistyczny miasta składają się poszczególne systemy funkcjonalne. Są to: transport, obejmujący transport dóbr materialnych, w tym również przesył mediów, transport i składowanie odpadów komunalnych, komunikacja zbiorowa i indywidualna, składowanie dóbr materialnych w dzielnicach przemysłowo-

\footnotetext{
${ }^{1}$ Dr inż. Grzegorz Zimon, Zakład Finansów i Bankowości, Wydział Zarządzania, Politechnika Rzeszowska, Al. Powstańców Warszawy 10, 35-959 Rzeszów, tel.: 01786516 33, e-mail: gzimon@ @rz.edu.pl (autor korespondencyjny).

${ }^{2}$ Dr Blanka Gosik, Instytut Turystyki i Rozwoju Ekonomicznego, Uniwersytet Łódzki, ul. Konstytucji 3 Maja 65/67, 97-200 Tomaszów Mazowiecki.
} 
handlowych i w sieciach handlowych miasta i sterowanie przepływami dóbr materialnych i osób. Współcześnie indywidualny transport zmotoryzowany zaczyna stanowić poważne zagrożenie dla sprawnego funkcjonowania miasta i płynnego transportu. Dlatego tak ważne stają się działania mające doprowadzić do zmian przyzwyczajeń, preferencji i mentalności mieszkańców. Powinny one spowodować coraz większe zainteresowanie transportem zbiorowym. Celem artykułu jest poznanie oceny funkcjonowania komunikacji miejskiej w dwóch różnej wielkości ośrodkach miejskich: średniego miasta Tomaszowa Mazowieckiego i dużego miasta, jakim jest Rzeszów. Badania miały charakter ankietowy i przeprowadzono je z mieszkańcami obu badanych miast.

\section{KONCEPCJA LOGISTYKI MIEJSKIEJ}

Logistykę miejską można zdefiniować jako zbiór założeń dążących do optymalizacji systemu miasta pod kątem planowania, sterowania i nadzorowania wszelkich procesów uwarunkowanych ruchowo, przebiegających w tym systemie, w wymiarze ekonomicznym, ekologicznym, socjalnym i technologicznym ${ }^{3}$. Inna bardziej uproszczona definicja logistyki miejskiej określa ją jako ogół procesów zarządzania przepływami osób, ładunków i informacji wewnątrz systemu logistycznego miasta, zgodnie z potrzebami i celami rozwojowymi miasta, z poszanowaniem ochrony środowiska naturalnego, uwzględniających to, że miasto jest organizacją społeczną, której nadrzędnym celem jest zaspokajanie potrzeb swoich użytkowników ${ }^{4}$.

Istnieją różne podejścia do logistyki miejskiej, dzięki czemu można ją definiować pod kątem ogólnym i cząstkowym, przyjmując różne konwencje: klasyczną, systemową i ekologiczną (tab. 1) $)^{5}$.

Przyjmując konwencję klasyczną (związaną z przemieszczeniami w sieci ulicznej), logistyka miejska obejmuje:

- logiczne porządkowanie czasowo-przestrzenne przepływu, zwłaszcza przez obszar centralny miast i aglomeracji, różnych rodzajów i natężeń strumieni ruchu samochodowego, autobusowego, tramwajowego, trolejbusowego)

- formułowanie założeń dla optymalizacji systemu miasta w zakresie planowania, sterowania i nadzorowania przebiegających w tym systemie procesów w wymiarze ekonomicznym, ekologicznym, technicznym i socjalnym

Według założeń konwencji systemowej, logistyka miejska to:

- logiczne ukształtowanie urbanistycznej przestrzeni ekonomicznej człowieka wraz z przestrzeganiem zasad minimalizacji nakładów logistycznych

Z kolei według założeń konwencji ekologicznej, logistyka miejska obejmuje:

- $\quad$ logiczne ukształtowanie przepływów i funkcjonowania systemu transportowego w zgodzie z zasadami zrównoważonego rozwoju

- $\quad$ stymulowanie i propagowanie działań służących redukcji kosztów zewnętrznych

- $\quad$ promocję czystego transportu miejskiego

${ }^{3}$ E. Gołębska, P. Czajak, D. Tomaszewska, Logistyka miejska XXI wieku, „EuroLogistics” 2001/3, s. 65-71.

${ }^{4}$ J. Szołtysek, Logistyczne aspekty zarządzania przepływami osób i ładunków w miastach, Akademia Ekonomiczna Katowice, Katowice 2005, s. 105.

${ }^{5}$ B. Tundys, Logistyka miejska. Koncepcje, systemy, rozwiąania, Difin, Warszawa 2008, s. 141. 
Jednym z najważniejszych celów zarządzania logistyki miejskiej jest organizowanie procesów logistycznych tak, aby przyczyniały się do rozwoju miasta. Zadania logistyki miejskiej można podzielić na trzy podstawowe grupy: ${ }^{6}$

- zadania o charakterze organizacyjnym, czyli kształtowanie struktur i procesów logistycznych;

- $\quad$ zadania o charakterze technicznym, stosowane techniki sterowania, informatyczne i komunikowania;

- zadania o charakterze ekonomicznym, ustalenie cen, taryf i opłat.

Najważniejsze obszary wyodrębnione w ramach logistyki miejskiej stanowią:

- transport ladunków;

- transport osobowy.

Transport osobowy można podzielić na przewozy zbiorowe i indywidualne. Głównymi zadaniami władz miasta są organizacja i kontrola transportu zbiorowego - pasażerskiego. Jest to transport miejski, który charakteryzuje się regularnością. Gdy jest sprawnie zorganizowany, może zmniejszyć wielkość transportu indywidualnego, który w wielu miastach istotnie przyczynia się do powstania zatorów. W strategicznych porach dnia prowadzi do zablokowania najważniejszych punktów miasta.

Podstawą do sprawnego funkcjonowania transportu ładunków i pasażerów jest zapewnienie odpowiedniej infrastruktury transportu. Infrastruktura transportu miejskiego składa się z następujących grup obiektów, które tworzą sieć transportową miasta ${ }^{7}$ : ulice, torowiska, napowietrzna sieć energetyczna, transformatory, dworce, przystanki, zajezdnie, parkingi, pozauliczne miejsca garażowania, miejsce wykonania czynności załadunkowych. Dodatkowo w celu usprawnienia komunikacji miejskiej bardzo często w wielu miastach można spotkać się z organizowaniem transportu rowerowego (rowery miejskie), podziałem miasta na specjalne strefy ruchu, tworzeniem buspasów.

Środki komunikacji miejskiej można podzielić na: ${ }^{8}$

- $\quad$ kolej regionalną;

- $\quad$ szybką kolej miejską;

- autobusy, trolejbusy, minibusy;

- tramwaje.

W wypadku korzystania z tych środków komunikacji miejskiej ważną rolę odgrywa organizacja systemów biletowych. Bardzo często problemem była słaba dostępność punktów sprzedaży. Obecnie bardzo często można spotkać się z automatami na przystankach lub w środkach transportu. Dostępna jest również opcja zapłaty za bilet za pomocą telefonów komórkowych. Rozwiązania te przyczyniają się do zniesienia ograniczenia związanego z brakiem miejsc, w których można było nabyć bilet.

Zoptymalizowany plan dotyczący funkcjonowania środków komunikacji miejskiej oraz jej infrastruktury powinien doprowadzić do odblokowania ulic, co ułatwi i przyspieszy przepływ osób, dostaw i informacji. Czas, terminowość to obecnie ważny

\footnotetext{
${ }^{6} \mathrm{M}$. Sołtysik, $O$ dynamice zmian $w$ logistyce, [w:] Kierunki rozwoju logistyki w świetle tendencji światowych, red. M. Sołtysik, Akademia Ekonomiczna Katowice, Katowice 2004, s. 23.

${ }^{7}$ M. Ciesielski, J. Długosz, Z. Gługsiewicz, O. Wyszomirski, Gospodarowanie w transporcie miejskim, Akademia Ekonomiczna, Poznań 1992, s. 28.

${ }^{8}$ M. Młynarczyk, M. Łysoń, Logistyka ustug miejskich, [w:] Logistyka ustug, red. G. Biesok, Cedewu, Warszawa 2013 , s. 91.
} 
element w walce o kontrahentów, klientów. Dlatego tak ważna dla przedsiębiorstw staje się logistyka miejska.

\section{TRANSPORT A FUNKCJONOWANIE MIASTA}

Do głównych zadań transportu w systemie logistycznym miasta należą: przewóz osób (transport pasażerski), transport towarów (transport zaopatrzenia) oraz wywóz odpadów i nieczystości. Zadania te realizowane są poprzez transport: samochodowy publiczny (autobusy i trolejbusy) i indywidualny, szynowy (tramwaje, szybkie kolejki miejskie, metro), wodny (w szczególnych wypadkach kanały i przeprawy promowe).

$\mathrm{Z}$ analizy struktury transportu gospodarczego w miastach wynika, że 1/3 wszystkich ruchów transportowych w mieście to transport gospodarczy towarowy, a $2 / 3$ to transport osobowy zarówno indywidualny, jak i publiczny ${ }^{9}$. Przemieszczenia osobowe mogą się odbywać przy użyciu transportu indywidualnego albo przy użyciu komunikacji zbiorowej. System miejskiego transportu zbiorowego stanowi jeden z podsystemów gospodarki miejskiej. Zaspokaja potrzeby miasta zarówno w zakresie miejskich, jak i podmiejskich przewozów mieszkańców ${ }^{10}$. Sprawność jego funkcjonowania zależy zarówno od jakości świadczonych usług przewozowych, jak również od wysokości nakładów finansowych na komunikację miejską.

Potrzeba przemieszczania się towarzyszy ludzkości od początków jej istnienia. Uciążliwość podróżowania pieszo zdeterminowała poszukiwania coraz to nowych rozwiązań technicznych w tej dziedzinie. Efektem są obecne możliwości transportu zarówno indywidualnego, jak i zbiorowego. Potrzeba komunikacyjna to chęć bądź konieczność jednostki lub określonej zbiorowości przemieszczania się z jednego miejsca $\mathrm{w}$ drugie za pomocą środka transportu. Potrzeby komunikacyjne, które powstają wewnątrz obszarów zurbanizowanych, i podróże z nich wynikające mają charakterystyczne właściwości. Zalicza się do nich ${ }^{11}$ :

- $\quad$ koncentrację na ograniczonej przestrzeni obszaru zurbanizowanego, co determinuje niewielką średnią odległość podróży;

- $\quad$ powszechność występowania, która wyraża się w dużej średniej liczbie przejazdów i podróży miejskich, realizowanych przez jednego mieszkańca;

- możliwość występowania, przejawiającą się w natężeniu ruchu pasażerskiego w jednym kierunku, w określonej jednostce czasu;

- $\quad$ nierównomierność występowania w czasie i przestrzeni.

Warto podkreślić, że charakter potrzeb zmienia się wraz z rozwojem społecznogospodarczym. Najogólniej wyróżnia się potrzeby przemieszczania się ${ }^{12}$ :

- $\quad$ między strefą zewnętrzną a miastem;

- wewnątrzmiejskie;

- $\quad$ między miastem a strefą zewnętrzną.

Samą istotę potrzeby można określić jako stan braku, związany z występującą różnicą pomiędzy stanem istniejącym a jego formą oczekiwaną czy preferowaną. Tak definiowa-

\footnotetext{
${ }^{9}$ T. Wagner, City-Logistik als Teil der Supply-Chain, Diss. Wissenchaft \& Praxis, Sternenfels 2002, s. 27.

${ }^{10}$ B. Tundys, Logistyka miejska. Koncepcje, systemy, rozwiazania, Difin, Warszawa 2008, s. 119.

${ }^{11}$ S. Dziadek, Systemy transportowe ośrodków zurbanizowanych, PWN, Warszawa 1991, s. 106.

${ }^{12}$ B. Meyer, Potrzeby komunikacyjne mieszkańców aglomeracji miejskich, „ZNUS Ekonomiczne problemy Transportu" 287 /2 (2000), s. 109
} 
na potrzeba wynika z różnic czasowych i przestrzennych między czynnikami niezbędnymi do realizacji działalności ludzkiej i utrzymywaniem więzi społecznych. Zatem potrzeby transportowe, rozumiane jako zmiany lokalizacji ładunków i osób w określonym czasie, to potrzeby realizowane $\mathrm{w}$ sposób zorganizowany i celowy ${ }^{13}$. Rozpatrując preferencje transportowe, nie sposób pominąć zagadnienie jakości, definiowanej jako spełnienie lub przekroczenie oczekiwań klienta. Jakość w transporcie zbiorowym rozumiana jest jako poziom usług, determinujący zadowolenie klienta (pasażera) z nabytego dobra lub usługi (przejazdu). Jakość usług przewozowych zależy od różnorakich czynników określanych jako kryteria jakości transportu miejskiego, czyli oczekiwania, wymagania klientów ${ }^{14}$. Na podstawie wymagań konstruowane są tzw. postulaty przewozowe, zależne od preferencji użytkowników, ale także od czynników lokalnych. Najbardziej popularne są cztery podstawowe postulaty takie jak: koszt, czas, dostępność i wygoda ${ }^{15}$. Bardzo często wymienia się jeszcze dodatkowe trzy ${ }^{16}$ :

- bezpieczeństwo - monitoring wnętrza pojazdu i przystanków, doświadczenie i odpowiednie umiejętności kierowców, odpowiedni stan autobusów;

- $\quad$ troskę o klienta - przyjazny stosunek personelu do pasażerów, odpowiednie kwalifikacje i prezencja personelu, stosowanie rekompensat za odstępstwa od obowiązujących standardów;

- $\quad$ ekologię - ekologiczny napęd oraz niski poziom hałasu generowanego przez pojazdy

\section{KOMUNIKACJA ZBIOROWA W BADANYCH MIASTACH}

Transport zbiorowy w Tomaszowie Mazowieckim jest realizowany przez Miejski Zakład Komunikacyjny w Tomaszowie Mazowieckim Spółka z ograniczoną odpowiedzialnością. Przedsiębiorstwo świadczy usługi dla mieszkańców miasta, a także okolicznych gmin. W wyposażeniu MZK znajduje się 40 autobusów, które kursują w ramach 18 linii. Według szacunków w dni powszednie z przewozów komunikacji zbiorowej korzysta ok. 14 tys. mieszkańców miasta i okolic. Najnowszy projekt związany z transportem miejskim w Tomaszowie Mazowieckim zakłada wprowadzenie darmowej komunikacji miejskiej. Przywilej ten ma być wprowadzony w życie od 1 września 2015 i ma być częścią tak zwanej karty tomaszowianina, którą miasto ma zamiar wprowadzić w przyszłości. Obecnie darmową komunikacją będą objęci jedynie mieszkańcy Tomaszowa Mazowieckiego, którzy są zameldowani i płacą w mieście podatki.

Transport zbiorowy w Rzeszowie realizuje Miejskie Przedsiębiorstwo Komunikacyjne w Rzeszowie Sp z o.o. Miejskie przedsiębiorstwo obsługuje transport zbiorowy na terenie miasta Rzeszowa i aglomeracji rzeszowskiej. MPK Rzeszów Sp. z o.o. prowadzi 51 linii autobusowych w tym: 33 linii miejskich; 12 linii podmiejskich; 3 linie nocne; 3 linie do specjalnych stref ekonomicznych.

\footnotetext{
${ }^{13}$ B. Gosik, G. Zimon, Ustugi transportowe w obstudze ruchu turystycznego, „Problemy Transportu i Logistyki” 28/843 (2014), s.43

${ }^{14}$ B.J. Milenkiewicz, K. Halicka, Ocena jakości ustug w transporcie zbiorowym na przykładzie Biatostockiej Komunikacji Miejskiej, „Economy and Management” 4/11 (2011), s. 79.

${ }^{15}$ J. Jackiewcz, P. Czech, J. Barcik, Standardy jakości ustug w komunikacji miejskiej, „Zeszyty Naukowe Politechniki Śląskiej” 2010, s. 56.

${ }^{16}$ O. Wyszomirski, Transport miejski. Ekonomika i organizacja, Wydawnictwo Uniwersytetu Gdańskiego, Gdańsk 2008, s. 108.
} 
Tabor MPK Rzeszów tworzy ponad 180 autobusów, wśród nich 80 to autobusy firmy autosan i mercedes wyprodukowane w latach 2013-2014. Udział autobusów niskopodłogowych i niskowejściowych we flocie to około $90 \%$. Udział autobusów zasilanych gazem to prawie $40 \%$. Widoczny jest też rozwój infrastruktury miejskiej. W autobusach pojawiają się tablice informacyjne o przystankach. Na przystankach zainstalowano ogrzewanie, postawiono tablice informacyjne stanowiące część Inteligentnego Systemu Transportowego. W Rzeszowie na 38 przystankach stoją biletomaty, wybudowano buspasy. W mieście powstaje kolejny nowy most. Wszystkie te działania mają za zadanie poprawić jakość świadczonych usług oferowanych przez MPK Rzeszów.

\section{OCENA KOMUNIKACJI ZBIOROWEJ W BADANYCH MIASTACH}

Ocenę komunikacji zbiorowej przeprowadzono w dwóch ośrodkach miejskich. Badaniami objęto średniej wielkości miasto Tomaszów Mazowiecki znajdujące się w województwie łódzkim i Rzeszów, duże miasto położone w województwie podkarpackim i będące jego stolicą. Celem autorów była analiza porównawcza transportu zbiorowego w badanych miastach. Podstawową metodą zastosowaną badaniach była ankieta przeprowadzona wśród mieszkańców zarówno Rzeszowa, jak i Tomaszowa Mazowieckiego. Za narzędzie badawcze posłużył opracowany przez autorów kwestionariusz ankiety. W ankiecie zawarto pytania ogólne dotyczące takich zagadnień jak częstotliwość i cel korzystania z komunikacji zbiorowej, a także rodzaj i cena używanych biletów. Jednak najważniejsze okazały się pytania mające na celu zbadanie opinii dotyczących transportu zbiorowego. Respondenci zostali poproszeni o ocenę jakości takich elementów infrastruktury transportu zbiorowego jak: dostępność komunikacji miejskiej, częstotliwość kursowania, punktualność, wygoda podróży, bezpieczeństwo podróżowania, bezpośredniość połączeń, skomunikowanie pojazdów komunikacji miejskiej, informacja (na przystankach, w pojazdach i na pojazdach), dostępność informacji o zmianach w rozkładzie, zewnętrzna identyfikacja autobusów, ułatwienia dla osób niepełnosprawnych, starszych i kobiet w ciąży, stosunek kierowców do pasażerów, warunki oczekiwania na przystankach, czystość na przystankach i czystość w autobusach. Ankietowani dokonywali oceny na podstawie pięciostopniowej skali, przy czym ocena 5 oznaczała ocenę najwyższą, a 1 - najniższą. Badania prowadzono w terminie od kwietnia do maja 2015 r. i łącznie przebadano 357 mieszkańców Rzeszowa i Tomaszowa Mazowieckiego.

Pierwsze pytanie zadane w ankiecie dotyczyło częstotliwości korzystania z komunikacji zbiorowej w badanych miastach. Okazało się, że mieszkańcy dużego miasta korzystają z transportu zbiorowego znacznie częściej niż mieszkańcy średniego miasta (rys. 1). Codziennie z komunikacji miejskiej korzysta 17,7\% respondentów z Rzeszowa, a kilka razy w tygodniu 31,4\%. Odpowiednio, te wartości dla Tomaszowa Mazowieckiego wynoszą $10,2 \%$ i 23,7\%. Kilka razy w miesiącu z transportu miejskiego korzysta 23,5\% rzeszowian i 18,6\% tomaszowian. Prawie połowa mieszkańców Tomaszowa Mazowieckiego (47,5\%) wskazała na „rzadziej niż raz w miesiącu”, z kolei w wypadku mieszkańców Rzeszowa wartość ta wyniosła 27,5\%. Oznacza to, że ankietowani z Tomaszowa Mazowieckiego znacznie częściej do przemieszczeń wewnątrzmiejskich używają transportu indywidualnego bądź poruszają się pieszo. Jest to możliwe ze względu na o wiele mniejszą powierzchnię i mniejsze natężenie ruchu ulicznego w tym mieście. 


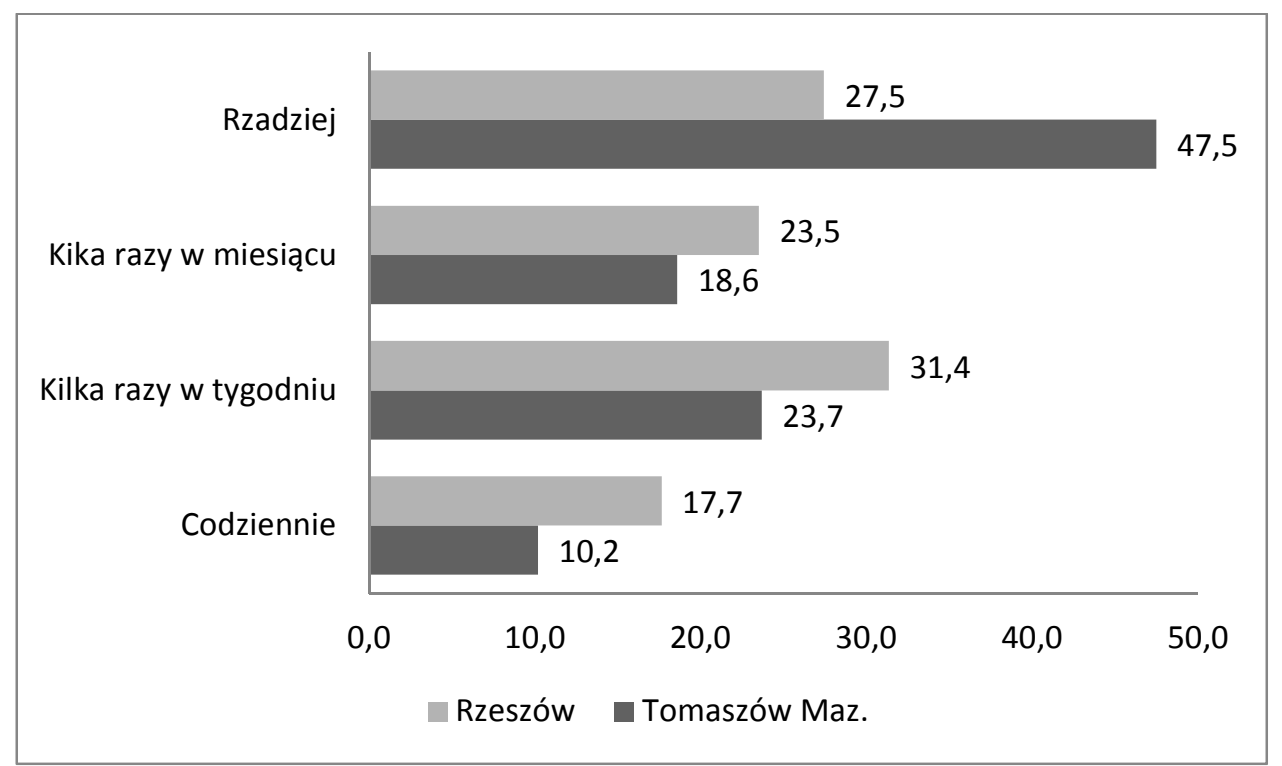

Rys. 1. Częstotliwość korzystania z komunikacji miejskiej (\%)

Źródło: opracowanie na podstawie badań.

Kolejne pytanie dotyczyło celu, w jakim respondenci korzystali z transportu miejskiego (rys. 2). Zarówno mieszkańcy Rzeszowa, jak i Tomaszowa Mazowieckiego jeżdżą komunikacją zbiorową w celach prywatnych: na zakupy, spotkać się ze znajomymi, do rodziny, do lekarza. W wypadku rzeszowian odsetek korzystających z komunikacji miejskiej w celach prywatnych wyniósł $68,6 \%$, a tomaszowian - 60,9\%. Z transportu zbiorowego korzysta w Rzeszowie dwukrotnie więcej uczniów i studentów (Rzeszów 32,4\%, Tomaszów Mazowiecki 14,1\%). Najprawdopodobniej wynika to z rangi badanych miast. Rzeszów jest ośrodkiem skupiającym kilka uczelni wyższych, w Tomaszowie Mazowieckim funkcjonuje jedynie filia Uniwersytetu Łódzkiego. Stąd tak duża różnica w popularności komunikacji zbiorowej wśród studentów. W wypadku dojazdu do pracy nie widać już znaczących różnic. W Tomaszowie Mazowieckim w celu dotarcia do miejsca pracy korzysta z komunikacji zbiorowej 32,6\% ankietowanych, a w Rzeszowie 28,8\%. 


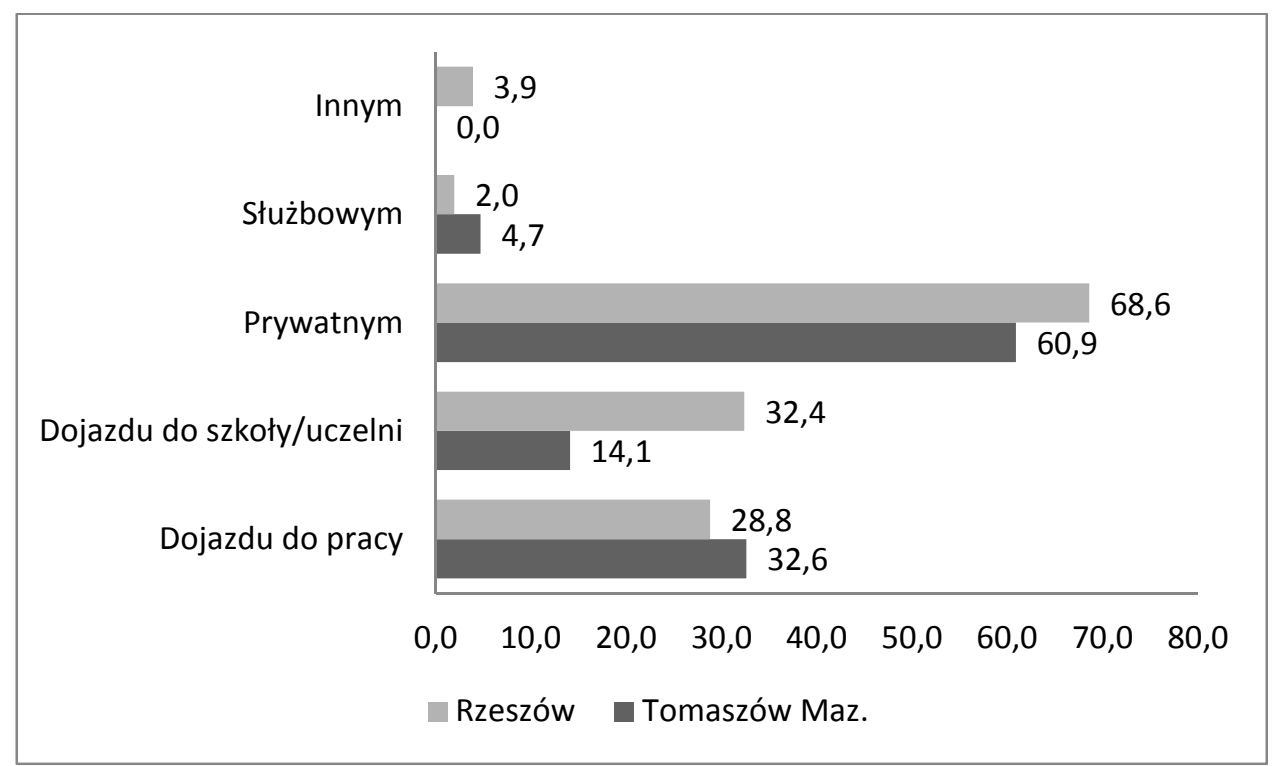

Rys. 2. Cel korzystania z komunikacji miejskiej (\%) (wyniki nie sumują się do 100\%) Źródło: opracowanie na podstawie badań.

Podczas prowadzenia badań, zapytano się respondentów o rodzaj biletu, z jakiego korzystają podczas podróżowania komunikacją miejską. Zaskoczeniem była przewaga biletu jednorazowego nad innymi rodzajami biletu (rys. 3). W Rzeszowie bilet jednorazowy wybiera 76,5\% badanych, a w Tomaszowie Mazowieckim - 84,3\%. Biletu miesięcznego używa $17,7 \%$ rzeszowian i $11,8 \%$ tomaszowian. Warto podkreślić, że respondenci z Rzeszowa znacznie częściej korzystają z innych typów biletów, np. semestralnego, czteroprzejazdowego (Rzeszów 11,8\%, Tomaszów Mazowiecki 3,9\%). 


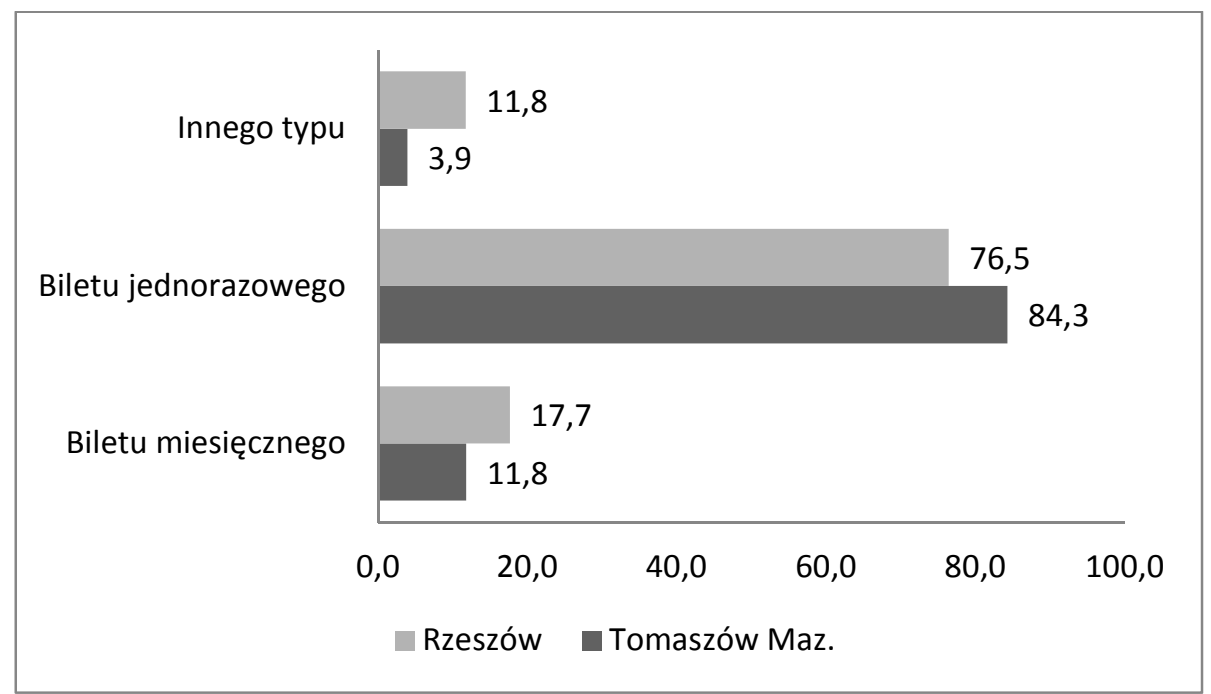

Rys. 3. Rodzaj biletu używanego podczas korzystania z komunikacji miejskiej (\%) (wyniki nie sumują się do 100\%)

Źródło: opracowanie na podstawie badań.

Mieszkańców badanych miast zapytano również o opinię na temat ceny biletów komunikacji miejskiej (rys. 4). Wyraźnie widać, że ankietowani z Tomaszowa Mazowieckiego znacznie gorzej oceniają cenę biletów. Za zbyt wysoką uważa ją 40,7\% tomaszowian. Rzeszowianie raczej uważają cenę biletów za przeciętną $(69,6 \%)$.

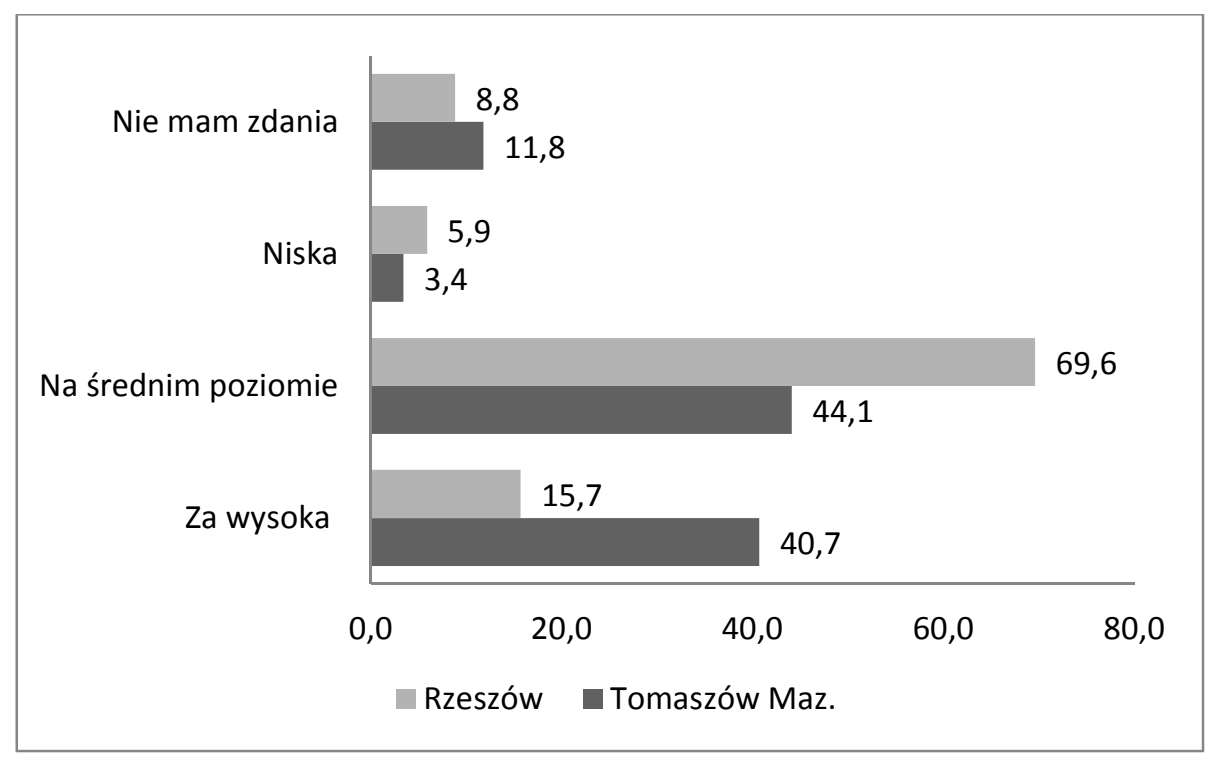

Rys. 4. Ocena ceny biletów komunikacji miejskiej (\%)

Źródło: opracowanie na podstawie badań. 
Głównym celem prowadzonych badań była analiza porównawcza oceny usług oferowanych przez komunikację miejską w dwóch miastach: Rzeszowie i Tomaszowie Mazowieckim. Podkreślić należy, że jakość usług inaczej może być odczuwana przez odbiorców, a inaczej przez dostawców. Aby zidentyfikować wielkość poszczególnych poziomów jakości, wykonywane są pomiary. Z punktu widzenia klienta jest to pomiar satysfakcji, z kolei w wypadku usługodawcy jest to pomiar wykonania. Celem pomiarów jest wykrycie ewentualnych odstępstw od przyjętych norm i podjęcie działań korygujących ${ }^{17}$. Gdy oczekiwania klienta odnośnie do poziomu świadczenia usługi są wyższe od jakości odczuwanej, rzeczywistej, mamy wówczas do czynienia ze zjawiskiem luki jakościowej bezwzględnej (rys. 5.). Innymi słowy, lukę jakościową oblicza się jako różnicę maksymalnych oczekiwań klienta w zakresie usługi i rzeczywistych ocen ankietowanych.

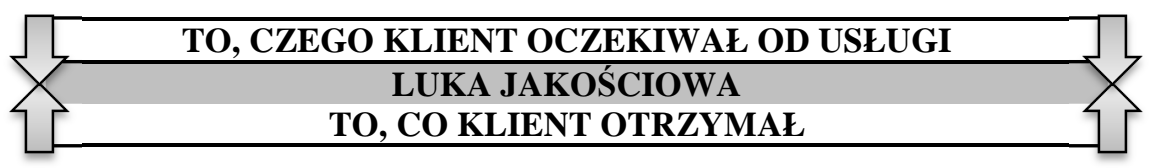

Rys. 5. Luka jakości usługi

Źródło: opracowanie własne na podstawie B.J. Milenkiewicz, K. Halicka, Ocena jakości ustug w transporcie zbiorowym na przykładzie Białostockiej Komunikacji Miejskiej, „Economy and Management" 4/11 (2011), s. 78.

W analizie oceny cech komunikacji miejskiej w badanych miastach wyraźnie widać, że transport zbiorowy znacznie lepiej wypada w oczach mieszkańców Rzeszowa (tab. 2). Średnia ocena dla wszystkich cech wyniosła tu 3,62, podczas gdy w Tomaszowie Mazowieckim jedynie 3,08. Co ciekawe, zarówno w Rzeszowie, jak i w Tomaszowie Mazowieckim najwyżej oceniane były te same elementy: zewnętrzna identyfikacja autobusów, informacja (na przystankach, w pojazdach i na pojazdach) i bezpieczeństwo podróżowania. W obu miastach jedną z najgorzej ocenianych cech było niestety skomunikowanie pojazdów komunikacji miejskiej.

Podsumowując, w Tomaszowie Mazowieckim najsłabiej oceniono takie elementy komunikacji miejskiej jak: skomunikowanie $(2,54)$, częstotliwość kursowania $(2,75)$ i bezpośredniość połączeń $(2,82)$. Z kolei za najlepsze ankietowani uznali: bezpieczeństwo podróżowania $(3,56)$, zewnętrzną identyfikację pojazdów $(3,56)$ i informację $(3,34)$. W wypadku Rzeszowa mieszkańcy najwyżej ocenili: zewnętrzną identyfikację pojazdów $(4,24)$, informację $(4,12)$, bezpieczeństwo podróżowania $(3,96)$ i czystość w autobusach $(3,94)$. Najsłabsze natomiast według rzeszowian są takie cechy, jak: dostępność informacji o zmianach w rozkładzie $(3,25)$, punktualność $(3,27)$, skomunikowanie pojazdów komunikacji miejskiej $(3,28)$ i stosunek kierowców do pasażerów $(3,29)$.

Przeprowadzone badania pozwoliły również na obliczenie luki jakościowej dla usług oferowanych przez komunikację miejską w badanych miastach (tab. 2). W wypadku Tomaszowa Mazowieckiego największa luka wystąpiła dla cech: skomunikowanie $(2,46)$, częstotliwość kursowania $(2,25)$ i bezpośredniość połączeń $(2,18)$, a najmniejsza dla: bezpieczeństwa podróżowania $(1,44)$, zewnętrznej identyfikacji pojazdów $(1,44)$ i infor-

\footnotetext{
${ }^{17}$ B.J. Milenkiewicz, K. Halicka, Ocena jakości ustug $w$ transporcie zbiorowym na przykładzie Białostockiej Komunikacji Miejskiej, „Economy and Management” 4/11 (2011), s. 78.
} 
macji (1,66). Z kolei w wypadku Rzeszowa największa luka jakościowa została odnotowana dla cech: dostępność informacji o zmianach w rozkładzie $(1,75)$, punktualność $(1,73)$, skomunikowanie pojazdów komunikacji miejskiej $(1,72)$ i stosunek kierowców do pasażerów (1,71), a najmniejsza dla cech: zewnętrzna identyfikacja pojazdów $(0,76)$, informacja $(0,88)$, bezpieczeństwo podróżowania $(1,04)$ i czystość w autobusach $(1,06)$.

Tabela 1. Cechy komunikacji miejskiej w ocenie mieszkańców Tomaszowa Mazowieckiego i Rzeszowa

\begin{tabular}{|c|c|c|c|c|c|}
\hline \multirow{2}{*}{ Lp. } & \multirow[b]{2}{*}{$\begin{array}{l}\text { Cecha funkcjonowania } \\
\text { komunikacji miejskiej }\end{array}$} & \multicolumn{2}{|c|}{ Ocena } & \multicolumn{2}{|c|}{ Luka jakościowa } \\
\hline & & $\begin{array}{c}\text { Tomaszów } \\
\text { Mazowiecki }\end{array}$ & Rzeszów & $\begin{array}{l}\text { Tomaszów } \\
\text { Mazowiecki }\end{array}$ & Rzeszów \\
\hline 1. & $\begin{array}{l}\text { Dostępność komunikacji miej- } \\
\text { skiej }\end{array}$ & 3,06 & 3,87 & 1,94 & 1,13 \\
\hline 2. & Częstotliwość kursowania & 2,75 & 3,49 & 2,25 & 1,51 \\
\hline 3. & Punktualność & 3,29 & 3,27 & 1,71 & 1,73 \\
\hline 4. & Wygoda podróży & 3,03 & 3,41 & 1,97 & 1,59 \\
\hline 5. & Bezpieczeństwo podróżowania & 3,56 & 3,96 & 1,44 & 1.04 \\
\hline 6. & Bezpośredniość połączeń & 2,82 & 3,64 & 2,18 & 1,36 \\
\hline 7. & $\begin{array}{l}\text { Skomunikowanie pojazdów } \\
\text { komunikacji miejskiej (przesiad- } \\
\text { ki z jednego autobusu na drugi) }\end{array}$ & 2,54 & 3,28 & 2,46 & 1,72 \\
\hline 8. & $\begin{array}{l}\text { Informacja (na przystankach, } \\
\text { w pojazdach i na pojazdach) }\end{array}$ & 3,34 & 4,12 & 1,66 & 0,88 \\
\hline 9. & $\begin{array}{l}\text { Dostępność informacji o zmia- } \\
\text { nach w rozkładzie }\end{array}$ & 3,07 & 3,25 & 1,93 & 1,75 \\
\hline 10. & $\begin{array}{l}\text { Zewnętrzna identyfikacja auto- } \\
\text { busów }\end{array}$ & 3,56 & 4,24 & 1,44 & 0,76 \\
\hline 11. & $\begin{array}{l}\text { Ułatwienia dla osób niepełno- } \\
\text { sprawnych, starszych i kobiet } \\
\text { w ciąży }\end{array}$ & 2,96 & 3,71 & 2,04 & 1,29 \\
\hline 12. & $\begin{array}{l}\text { Stosunek kierowców do pasaże- } \\
\text { rów }\end{array}$ & 3,10 & 3,29 & 1,9 & 1.71 \\
\hline 13. & $\begin{array}{l}\text { Warunki oczekiwania na przy- } \\
\text { stankach }\end{array}$ & 2,92 & 3,35 & 2,08 & 1,65 \\
\hline 14. & Czystość na przystankach & 2,88 & 3,51 & 2,12 & 1,49 \\
\hline 15. & Czystość w autobusach & 3,28 & 3,94 & 1,72 & 1,06 \\
\hline & cena średnia & 3,08 & 3,62 & 1,92 & 1,38 \\
\hline
\end{tabular}

Źródło: opracowanie na podstawie badań.

\section{PODSUMOWANIE}

W przeprowadzonych badaniach wykazano, że mieszkańcy Rzeszowa lepiej oceniają komunikację miejską w porównaniu z mieszkańcami Tomaszowa. Średnia dla wszystkich cech w Rzeszowie wynosi 3,62, dla Tomaszowa zaś wynik ten wynosi 3,08. Stwierdzono, że rzeszowianie częściej korzystają z komunikacji miejskiej. Jest to spowodowane dobrą dostępnością, wygodą i szybkością, jakie daje transport miejski. Duży wpływ na poprawę jakości oferowanych usług transportowych ma wprowadzenie buspasów, elektronicznych 
biletomatów znajdujących się przy przystankach i w autobusach oraz elektronicznych tablic informacyjnych. Zwiększyło to punktualność i szybkość oferowanych usług.

Tomaszów to średniej wielkości miasto. W wiele miejsc można w zasadzie dojść pieszo i to wpływa na mniejsze zainteresowanie komunikacją miejską. Dodatkowo w mieście ruch jest nieduży, co pozwala mieszkańcom korzystać z własnych środków transportu. Transport indywidualny jest wygodniejszy, szybszy i te korzyści sprawiają, że komunikacja miejska w Tomaszowie jest mniej popularna. W celu zwiększenia zainteresowania transportem zbiorowym w 2015 r. mają być wprowadzone darmowe bilety dla mieszkańców. Jest duża szansa, że dzięki temu wzrośnie zainteresowanie komunikacją miejską.

Działania podjęte przez miasto Rzeszów wpłynęły pozytywnie na jakość podróżowania i lepszy przepływ informacji. Zwiększyły punktualność i dostępność do biletów. Rzeszów to miasto, w którym duży procent mieszkańców korzysta z transportu indywidualnego, co powoduje uporczywe korki. Wprowadzenie buspasów znacznie zwiększyło punktualność autobusów, co przełożyło się na zainteresowanie transportem zbiorowym miejskim. Brak miejsc parkingowych również skłania mieszkańców do wyboru transportu zbiorowego. Aby zmniejszyć poziom użytkowania samochodów, wprowadzono możliwość wypożyczenia rowerów miejskich oraz wybudowano sieć ścieżek rowerowych. Działania te spowodowały większe zainteresowanie tym środkiem lokomocji.

Podsumowując, zarówno Rzeszów, jak i Tomaszów wprowadzają nowe rozwiązania w celu zwiększenia zainteresowania i uatrakcyjnienia transportu zbiorowego miejskiego. Rozwój transportu zbiorowego miejskiego jest jedynym rozwiązaniem, które pozwoli udrożnić komunikację miejską. W innym wypadku wzrost korzystania z transportu indywidualnego może doprowadzić do zablokowania miast. Na „bezproblemową” naprawę logistyki miejskiej będzie wtedy już za późno. Wzrosną koszty modernizacji, a proces będzie długotrwały, co negatywnie wpłynie na rozwój miast i sytuację ekonomiczną mieszkańców.

\section{LITERATURA}

[1] Ciesielski M., Długosz J., Gługsiewicz Z., Wyszomirski, O gospodarowaniu w transporcie miejskim, Akademia Ekonomiczna, Poznań 1992.

[2] Dziadek S., Systemy transportowe ośrodków zurbanizowanych, PWN, Warszawa 1991.

[3] Gołębska E., Czajak P., Tomaszewska D., Logistyka miejska XXI wieku, „EuroLogistics” 2001/3.

[4] Gosik B., Zimon G., Ustugi transportowe w obstudze ruchu turystycznego, „Problemy Transportu i Logistyki. Zeszyty Naukowe Uniwersytetu Szczecińskiego” 843/28 (2014).

[5] Jackiewcz J., Czech P., Barcik J., Standardy jakości usług w komunikacji miejskiej, „Zeszyty Naukowe Politechniki Śląskiej” 2010.

[6] Meyer B., Potrzeby komunikacyjne mieszkańców aglomeracji miejskich, „ZNUS. Ekonomiczne problemy Transportu" 287/2 (2000).

[7] Milenkiewicz B.J., Halicka K., Ocena jakości ustug w transporcie zbiorowym na przykładzie Białostockiej Komunikacji Miejskiej, „Economy and Management” 4/11 (2011).

[8] Młynarczyk M., Łysoń M., Logistyka ustug miejskich, [w:] Logistyka ustug, red. G. Biesok, Cedewu, Warszawa 2013.

[9] Sołtysik M., O dynamice zmian w logistyce [w:] Sottysik M. (red.) Kierunki rozwoju logistyki $w$ świetle tendencji światowych, Akademia Ekonomiczna Katowice, Katowice 2004.

[10] Szołtysek J., Logistyczne aspekty zarzadzania przepływami osób i ładunków w miastach, Akademia ekonomiczna Katowice, Katowice 2005.

[11] Tundys B., Logistyka miejska. Koncepcje, systemy, rozwiazania, Difin, Warszawa 2008. 
[12] Wagner T., City-Logistik als Teil der Supply-Chain, Diss. Wissenchaft \& Praxis, Sternenfels 2002.

[13] Wyszomirski O., Transport miejski. Ekonomika i organizacja, Wydawnictwo Uniwersytetu Gdańskiego, Gdańsk 2008.

\section{URBAN LOGISTICS EVALUATION OF COLLECTIVE TRANSPORT ON THE EXAMPLE OF TOMASZÓW MAZOWIECKI AND RZESZÓW}

Contemporary logistics describes a city in two aspects. First, as a link in a logistic chain of a logistic system in a country, second, as an independent urban system. Logistics systems of a city can be divided into separate functional systems. Those systems include: transportation of material goods, transmission of media, transport and land filling of residential waste, mass and individual transit, allocation of material assets to city malls and to industrial and commercial districts, and the control of the flow of tangible goods and people. It should be emphasized that both individual and public human transportation encompasses two-thirds of all urban transport, and the remaining one-third is economic freight transportation. Passenger movements take place by either individual or mass public transport. Nowadays, the increased volume of individual motorized transport starts to affect efficient functioning of a city by disrupting smooth flow of urban transportation. Therefore, it is becoming more and more important to take action in changing the habits and mentality of the residents and to make them more interested in public transportation. The goal of this research was to investigate the public opinion on the functioning of public transportation in two different sized cities: medium Tomaszow Mazowiecki, and large Rzeszow. The investigators conducted surveys with residents from both cities.

Keywords: logistics, communication, city, residents

DOI: $10.7862 /$ rz.2015.mmr.29

Tekst złożono w redakcji: czerwiec 2015

Przyjęto do druku: lipiec 2015 